\title{
ПЕРСПЕКТИВЫ ИСПОЛЬЗОВАНИЯ ПСЕВДОМОНАД, АССОЦИИРОВАННЫХ С ПОЧВЕННЫМИ ЛЮМБРИЦИДАМИ, ПРОТИВ ВОЗБУДИТЕЛЕЙ КОРНЕВЫХ ГНИЛЕЙ ЯРОВЫХ ЗЕРНОВЫХ
}

\author{
О.М. МИНАЕВА', 2, Е.Е. АКИМОВА', 2, Н.Н. ТЕРЕЩЕНКО1, 2, А.В. КРАВЕЦ1, \\ Т.И. ЗЮБАНОВА ${ }^{1,2}$, М.В. АПЕНЫШЕВА ${ }^{2}$
}

В настоящее время основой повышения урожайности сельскохозяйственных культур становится высокая культура земледелия, в том числе экологически безопасное применение химических удобрений и пестицидов и их замещение на биопрепараты с аналогичным спектром действия. Актуален как поиск новых видов, штаммов и изолятов бактерий-антагонистов, перспективных для использования в качестве агентов биологического контроля, так и исследование механизмов антифунгальной активности, в частности связи между способностью подавлять рост и развитие тест-объектов в модельных условиях и в агроценозе. Целью настоящей работы была оценка возможности применения бактерий, выделенных из копролитов дождевых червей, как основы биопрепарата для контроля фитопатогенных грибов - возбудителей корневых гнилей зерновых культур. Опыты проводили в 2013-2015 годах. В предварительном скрининге на наличие фунгистатической и ростостимулирующей активностей в лабораторных тестах были отобраны два штамма - Pseudomonas sp. GS4 и Pseudomonas sp. PhS1. Фунгистатический эффект определяли по способности бактерий уменьшать скорость роста грибных колоний на агаризованной питательной среде и снижать зараженность семян мягкой пшеницы (Triticum aestivum L.) сорта Иргина возбудителями инфекций в тесте с использованием рулонов стерильной фильтровальной бумаги. Контролем служили семена, замоченные в водопроводной воде. В качестве эталона использовали обработку семян разрешенным к применению на территории Российской Федерации химическим фунгицидом Дивиденд Стар KC (Dividend ${ }^{\circledR}$ Star, «Syngenta AG», Швейцария) (действующие вещества дифеноконазол -30 г/л, ципроконазол $-6,3$ г/л) в рекомендуемых нормах расхода. Для оценки антифунгальной активности бактерий в полевых условиях проводили учеты корневых гнилей в фазы кущения и начала цветения у растений мягкой пшеницы сорта Иргина и ячменя (Hordeum vulgare L.) сорта Ача. В лабораторном эксперименте показано статистически значимое $($ p $<0,05)$ снижение скорости роста фитопатогенных грибов Fusarium oxysporum, Bipolaris sorokiniana и Alternaria spp. (в 1,5-2,5 раза по сравнению с контролем). Выявлено уменьшение (p $<0,05)$ общей зараженности семян возбудителями инфекций во всех вариантах бактеризации на 53-76 \% относительно контроля. Влияние бактерий в экспериментах in planta оценивалось в малых модельных системах. Полученные результаты показали статистически значимое (р < 0,05) снижение распространенности корневых гнилей при бактеризации Pseudomonas sp. GS4 на 33-37 \%, Pseudomonas sp. PhS1 - на 57-60 \%; индекс развития корневых гнилей снизился соответственно в 2,1-2,4 раза и в 3,3-3,5 раза. Учет численности микроорганизмов в зоне ризосферы, проведенный в фазу начала цветения зерновых в вегетационном опыте, выявил тенденцию к увеличению общей численности микроорганизмов на 19-70 \% в зависимости от сельскохозяйственной культуры и варианта бактеризации. Численность фосфатмобилизующих бактерий в ризосфере пшеницы в опыте была в среднем в 5,5-7,2 раза выше, чем в контроле, в ризосфере ячменя - в 2,1-3,2 раза. Результаты учета корневых гнилей в вегетационные сезоны 2013-2015 годов показали эффективность использования как монокультур, так и комплексной бактеризации: установлено снижение индекса развития корневых гнилей пшеницы и ячменя соответственно на 6,5-57,6 и 18,6-50,0 \% в зависимости от бактериальной культуры и погодных условий вегетационного периода. Наибольшую биологическую эффективность изолятов наблюдали в начале цветения растений.

Ключевые слова: биоконтроль, ризобактерии, Pseudomonas, Eisenia fetida, антифунгальная активность, фитопатоген, Bipolaris, Alternaria.

Антифунгальная активность - относительно обычная характеристика бактерий, дающая экологическое преимущество в средах, которые поддерживают рост смешанной бактериальной и грибной флоры. Существует ряд механизмов, которые способствуют подавлению роста одного организма другим: конкуренция за ограниченную поставку питательных веществ, продукция сидерофоров (1-3), антибиотиков, ферментов и других 
соединений $(4,5)$. Активность бактерий in vitro, как правило, положительно коррелирует с их способностью ингибировать рост фитопатогенов и со стимулирующей активностью in vivo $(1,6,7)$. Однако фунгистатическое и стимулирующее рост растений действие бактерий, показанное в лабораторных условиях, не всегда подтверждается опытами in vivo (8-10).

Несмотря на то, что биопрепараты на основе бактерий-антагонистов широко используются в сельском хозяйстве и положительно воздействуют на рост и развитие растений, в ранних исследованиях отмечали нестабильность получаемых при этом результатов $(11,12)$. Более детальное изучение показало (13-15), что эффективность биопрепаратов зависит от ряда факторов: режима культивирования штаммов микроорганизмов, препаративной формы, способов и сроков хранения, свойств почвы, агроклиматических условий, растения-хозяина, а также способности штамма создавать прочные симбиотические ассоциации с той или иной возделываемой культурой и состояния микробного сообщества почвы при высеве семян, обработанных биопрепаратом.

Ряд авторов успешно использовали в защите растений сочетания нескольких бактериальных штаммов $(16,17)$. Показано, что наиболее эффективно развитие заболеваний контролирует смесь штаммов и применение двухкомпонентных биофунгицидов $(18,19)$. Создание пар микробных штаммов в определенных случаях позволяет уменьшить рабочие концентрации биопрепарата и улучшить его качество $(7,14)$. В большинстве указанных работ бактерии рода Pseudomonas были одним из компонентов биопрепарата. Этот выбор основан на высокой антифунгальной активности и многофункциональном влиянии псевдомонад на рост и развитие растений $(1,4,11)$. Вторым компонентом может быть бактерия, также имеющая широкое распространение в ризосфере растений и способная стимулировать рост и развитие не только их, но и основного компонента биопрепарата.

Для активного применения биопрепаратов в современных агротехнологиях требуется поиск эффективных штаммов, перспективных в качестве агентов биологического контроля фитопатогенов в разных агроценотических условиях. Ускорить процесс разработки таких биопрепаратов помогают углубленные исследования связи между проявлением биологической активности бактерий в лабораторных и полевых условиях.

Мы впервые установили, что бактериальные штаммы рода Pseudomonas, выделенные из копролитов, снижают зараженность мягкой пшеницы возбудителями семенных инфекций в лабораторных экспериментах, что коррелирует с их способностью подавлять развитие грибов - возбудителей корневых гнилей в условиях агроценоза.

Целью настоящей работы была оценка возможности применения бактерий, выделенных из копролитов дождевых червей, как основы биопрепарата для контроля фитопатогенных грибов - возбудителей корневых гнилей зерновых культур.

Методика. Лабораторные и полевые испытания проводили в 20132015 годах. Бактериальные культуры Pseudomonas sp. GS4 и Pseudomonas sp. $\mathrm{PhS1}$ выделяли из копролитов дождевых червей (Eisenia fetida) после 1 мес их культивирования на торфо-навозном субстрате (соотношение 1:2) при прямом высеве на питательную среду на основе гидролизата рыбной муки (ГРМ-бульон) (ФБУН Государственный научный центр прикладной микробиологии и биотехнологии, Россия). Штаммы отбирали после предварительного скрининга на наличие фунгистатической и ростостимулирующей активности в лабораторных тестах (9). 
Жидкие накопительные культуры получали при выращивании в колбах на ГРМ-бульоне (объем 250 мл со 100 мл среды) на шейкере ES20/60 («Biosan», Латвия) при 180 об/мин и $28 \pm 0,5{ }^{\circ} \mathrm{C}$ до достижения численности бактерий $1 \times 10^{9}-9 \times 10^{9}$ кл/мл. В состав ГРМ-бульона входили панкреатический гидролизат рыбной муки (8 г/л), пептон ферментативный (8 г/л), натрия хлорид (4 г/л). Численность бактерий контролировали подсчетом в камере Горяева (увеличение $\times 400)$.

Тест-объектами для оценки антагонистической активности бактерий служили фитопатогенные грибы Fusarium oxysporum, Bipolaris sorokiniana и Alternaria spp. (коллекция лаборатории биологической защиты растений Новосибирского государственного аграрного университета). Их культивировали на картофельно-глюкозном 2 \% агаре (картофельный экстракт - 0,23 л, глюкоза - 20,0 г, водопроводная вода $-0,77$ л). Для определения антифунгальной активности на твердые агаризованные среды штрихом в линию от края до края чашки Петри высевали бактериальные суспензии (по одной на вариант). Чашки инкубировали 2 сут. Затем на поверхность среды в центре свободной площади помещали цилиндрический агаровый блок диаметром 2 мм с 6-суточным мицелием гриба. После этого чашки помещали в термостате при температуре $24 \pm 1,0{ }^{\circ} \mathrm{C}$. Каждые 24 ч измеряли радиус роста грибной колонии в направлении к штриху (контроль - радиус роста колонии гриба в отсутствие бактерий). Фунгистатический эффект оценивали по снижению скорости роста грибных колоний на плотной питательной среде в вариантах с бактериальным штрихом по сравнению с контролем (20).

В лабораторных экспериментах семена мягкой пшеницы (Triticum aestivum L.) сорта Иргина замачивали на 20 мин в бактериальной суспензии монокультур опытных штаммов $\left(1 \times 10^{7}-5 \times 10^{7}\right.$ кл/мл). В варианте с совместной инокуляцией количество суспензии каждого штамма бактерии уменьшали вдвое - по $5 \times 10^{6}-25 \times 10^{6}$ кл/мл. Контролем служили семена, замоченные в водопроводной воде, эталон - обработка семян разрешенным к применению на территории Российской Федерации химическим фунгицидом Дивиденд Стар KC (Dividend® Star, «Syngenta AG», Швейцария; действующие вещества: дифеноконазол - 30 г/л, ципроконазол 6,3 г/л) в рекомендуемых нормах расхода. Фунгистатический эффект бактерий оценивали по снижению зараженности семян возбудителями семенных инфекций при фитопатологическом анализе с использованием рулонов стерильной фильтровальной бумаги $(10,20)$. Влияние бактерий в экспериментах in planta изучали в малых модельных экосистемах, состоящих из трех звеньев: субстрат (стерильный крупный речной песок)- растениехозяин (пшеница)-бактерии. Бактерии вносились в систему из расчета $1 \times 10^{6}$ кл/семя. Контрольные и опытные сосуды помещали в климатокамеру (GC-300TLH, «Jeio Tech», Корея) при интенсивности освещения 10 клк, 16-часовым световым периоде и температуре $22-24{ }^{\circ} \mathrm{C}$ на 10 сут. После этого у проростков оценивали наличие признаков корневых гнилей и степень поражения в баллах (20).

Полевые эксперименты (стационар Сибирского НИИ сельского хозяйства и торфа, п. Лучаново, Томская обл.) выполняли на пшенице сорта Иргина и ячмене (Hordeum vulgare L.) сорта Ача. Почва - серая оподзоленная среднесуглинистая, $\mathrm{pH} 5,0$, содержание гумуса 4,87 \%, поглощенных оснований - 24,9 мг-экв/100 г абсолютно сухого вещества (а.с.в.) почвы, $\mathrm{N}-\mathrm{NH}_{4}-2,66, \mathrm{~N}-\mathrm{NO}_{3}-8,48, \mathrm{P}_{2} \mathrm{O}_{5}-236,5$ и $\mathrm{K}_{2} \mathrm{O}-99,2$ мг/кг а.с.в. Опыты закладывали по Б.А. Доспехову (23). Повторность 3-кратная, размещение вариантов систематическое, площадь делянок $40 \mathrm{M}^{2}$, учетная 
площадь - 32 м². Доза внесения азотных удобрений (мочевина) - 45 кг/га по азоту $\left(\mathrm{N}_{45}\right)$. Семена перед посевом бактеризовали накопительными культурами (рабочий титр $1 \times 10^{7}-5 \times 10^{7}$ кл/мл) с нормой расхода 100 мл/10 кг зерна. Норма высева семян составляла 6,5 млн/га для пшеницы, 5,5 млн/га - для ячменя.

Для оценки фунгистатической активности исследуемых бактерий в фазы кущения и начала цветения отбирали растения (для всех повторностей и вариантов минимум по 100 в случайном порядке). Учитывали число здоровых, пораженных и погибших растений, а также степень поражения в баллах, на основании чего рассчитывали показатели распространенности и индексы развития болезней $(10,22)$.

Численность микроорганизмов в ризосфере определяли методом прямого посева на элективные питательные среды из серии последовательных разведений почвенной взвеси. Общую численность бактерий учитывали на ГРМ-агаре, численность фосфатмобилизующих бактерий - на агаризованной среде Муромцева $\left(\mathrm{K}_{2} \mathrm{SO}_{4}-0,2, \mathrm{MgSO}_{4} \cdot 7 \mathrm{H}_{2} \mathrm{O}-0,2\right.$, глюкоза - 10, аспарагин - 1,0, $\mathrm{CaCl}_{2}-3,3, \mathrm{Na}_{3} \mathrm{PO}_{4}-3,8$, агар-агар - 15 г/л), микромицетов - на среде Чапека $\left(\mathrm{K}_{2} \mathrm{HPO}_{4}-1,0, \mathrm{NaNO}_{3}-2,0, \mathrm{KCl}-\right.$ $0,5, \mathrm{FeSO}_{4} \cdot 7 \mathrm{H}_{2} \mathrm{O}-0,1$, глюкоза $-20, \mathrm{MgSO}_{4} \cdot 7 \mathrm{H}_{2} \mathrm{O}-0,5$, агар-агар 15 г/л с подкислением соляной кислотой до $\mathrm{pH}$ 5,5).

Полученные данные обрабатывали с помощью пакета STATISTICA 6.0 («StatSoft, Inc.», США). Скорость роста грибных колоний вычисляли с использованием метода линейной регрессии. Результаты фитопатологических анализов семян, а также распространенность заболеваний в полевых экспериментах в вегетационный период представлены с учетом критерия Фишера для вероятности меныше $25 \%$ и больше $75 \%$. Статистическую значимость оценивали сравнением выборочных долей с учетом $t$-критерия Стьюдента для 95 \% уровня значимости для вероятностей 25-75 \% включительно, для других значений вероятностей - с учетом критерия Фишера. Индексы развития корневых гнилей, численность микроорганизмов представлены в виде средней арифметической величины $(M)$ с доверительным интервалом $( \pm \sigma)$ с учетом $t$-критерия Стьюдента для уровня значимости $95 \%$, их сравнение проводили с учетом $t$-критерия Стьюдента (различия считали статистически значимыми при $\mathrm{p}<0,05$ ).

Результаты. Лабораторные эксперименты - неотъемлемая часть разработки биопрепаратов для защиты растений, которая позволяет сократить сроки их внедрения в производство. Последующие испытания перспективных микробных интродуцентов и биопрепаратов на их основе в полевых условиях осуществляются в течение нескольких различающихся по погодным условиям вегетационных периодов.

Мы провели серию экспериментов по изучению влияния бактериальных изолятов, выделенных из копролитов, на рост и развитие ряда фитопатогенных грибов в стандартном тесте с бактериальным штрихом. Бактериальные культуры, изолированные из копролитов дождевых червей, на основании морфологических и физиолого-биохимических признаков были отнесены к роду Pseudomonas (23). Бактерии представляли собой короткие, одиночные, подвижные, неспорообразующие грамотрицательные палочки, хорошо развивающиеся на органических средах. Они разжижали желатин, гидролизовали крахмал, проявляли каталазную активность, восстанавливали нитраты до нитритов, образовывали кислоту на средах с глюкозой и сахарозой, были аэробами. Один из отобранных штаммов - Pseudomonas sp. PhS1 образовывал желтый растворимый в воде пигмент и мобилизовал труднорастворимые фосфаты. 
Установлено, что в присутствии бактерий скорость роста всех изучаемых грибов статистически значимо $(\mathrm{p}<0,05)$ снижалась по сравнению с контролем (в 1,5-2,5 раза, табл. 1). Поскольку уменьшение скорости роста грибных колоний не требовало прямого контакта гиф гриба с бактериальным штрихом, а микромицет прекращал свой рост, не достигая его, то можно заключить, что антифунгальный эффект был связан с растворимыми и диффундирующими в среду метаболитами бактерий.

1. Влияние штаммов псевдомонад, выделенных из копролитов дождевых червей, на скорость радиального роста (мм/ч) чистых культур фитопатогенных грибов $(M \pm \sigma$, лабораторный опыт)

\begin{tabular}{l|c|c|c}
\hline \multicolumn{1}{c|}{ Вариант } & Fusarium oxysporum & Bipolaris sorokiniana & Alternaria spp. \\
\hline Контроль (вода) & $0,24 \pm 0,014$ & $0,22 \pm 0,021$ & $0,30 \pm 0,019$ \\
Pseudomonas sp. GS4 & $0,15 \pm 0,012^{*}$ & $0,09 \pm 0,006^{*}$ & $0,15 \pm 0,046^{*}$ \\
Pseudomonas sp. PhS1 & $0,11 \pm 0,010^{*}$ & $0,07 \pm 0,005^{*}$ & $0,11 \pm 0,011^{*}$ \\
* Различия с контролем статистически значимы при р $<0,05$. &
\end{tabular}

Согласно данным литературы, эффект ингибирования роста грибов бактериями рода Pseudomonas связан прежде всего с выделением псевдомонадами различных антибиотиков, среди которых известны феназин-1карболовая кислота, производные флороглюцина, пирролнитрин и другие соединения $(1,5,13)$. Помимо антибиотиков важную роль в ингибировании играют выделяемые бактериями этого рода сидерофоры - желтозеленые пигменты, осуществляющие транспорт железа. Они связывают ионы трехвалентного железа и образуют с ним стабильные комплексы, в результате грибы лишаются необходимого элемента питания, что приводит к приостановке их развития $(4,5,15)$. Бактерии Pseudomonas sp. PhS1 на МПА выделяли желтый диффундирующий в среду пигмент. По-видимому, в ингибировании ими роста фитопатогенных грибов наиболее важную роль играет сидерофорный механизм. Для бактерий Pseudomonas sp. GS4 пигментация отсутствовала, их антифунгальная активность, возможно, была связана с продуцированием иных антибиотических веществ.

2. Снижение зараженности семян относительно зараженности в контроле без обработки (\%), обусловленное бактеризацией и химической обработкой $(M \pm \sigma$, мягкая пшеница Triticum aestivum L., сорт Иргина, лабораторный опыт)

\begin{tabular}{l|c|c|c|c}
\hline \multicolumn{1}{c|}{ Вариант } & $\begin{array}{l}\text { Общая } \\
\text { пораженность }\end{array}$ & Гельминтоспориоз & Альтернариоз & Бактериоз \\
\hline Pseudomonas sp. GS4 & $54,0 \pm 2,0^{*}$ & $35,5 \pm 3,4$ & $61,3 \pm 22,4$ & $64,5 \pm 21,0$ \\
Pseudomonas sp. PhS1 & $76,2 \pm 2,1^{*}$ & $100,0 \pm 1,0^{*}$ & $29,0 \pm 7,8$ & $100,0 \pm 1,0^{*}$ \\
Pseudomonas sp. (GS4 + PhS1) & $64,5 \pm 1,9^{*}$ & $100,0 \pm 1,0^{*}$ & $58,0 \pm 23,0$ & $35,5 \pm 9,0$ \\
Дивиденд Стар, KC & $74,1 \pm 1,7^{*}$ & $69,7 \pm 7,2^{*}$ & $25,4 \pm 7,9$ & $100,0 \pm 1,0^{*}$ \\
\hline * Различия с контролем статистически значимы при p $<0,05$. & & \\
\hline
\end{tabular}

Для всех вариантов бактеризации наблюдалось статистически значимое $(\mathrm{p}<0,05)$ снижение общей пораженности семян возбудителями семенных инфекций (табл. 2). Обработка семян пшеницы монокультурой бактерий Pseudomonas sp. PhS1 была самой эффективной, обусловив наибольшее снижение зараженности. Степень воздействия этого штамма и химического протравителя оказалась сопоставимой.

Модельные вегетационные эксперименты in planta также показали высокую биологическую активность изучаемых бактерий. Было выявлено статистически значимое ( $p<0,05)$ уменьшение распространенности корневых гнилей в вариантах с бактеризацией штаммом Pseudomonas sp. GS4 на 33-37 \%, штаммом Pseudomonas sp. PhS1 - на 57-60 \%, индекс развития корневых гнилей снижался соответственно в 2,1-2,4 и в 3,3-3,5 раза по сравнению с контролем. 
Погодные условия вегетационного сезона 2013 года были достаточно благоприятными для роста и развития сельскохозяйственных культур, используемых нами в полевых тестах. Начало и окончание вегетационного периода характеризовались низкими температурами с частыми и интенсивными осадками, II и III декада июля, а также начало августа оказались жаркими при дефиците осадков. Начало сезона в 2014 году складывалось неблагоприятно (низкие температуры в мае и начале июня с частыми и интенсивными осадками). Остальной период, как и сезон 2013 года, в целом характеризовался удовлетворительными условиями для роста и развития растений. В 2015 году накопление суммы эффективных температур происходило с апреля по сентябрь, наблюдалось превышение количества осадков относительно нормы в мае, июле, августе и сентябре, июнь был засушливым.

Микробиологический анализ ризосферы растений пшеницы и ячменя выявил тенденцию к увеличению общей численности микроорганизмов в опытных вариантах. Заметное сокращение общей численности низших грибов при резком росте количества представителей рода Trichoderma свидетельствовало об уменьшении в составе микробного ризосферного сообщества доли потенциально опасных микроорганизмов и увеличении количества агентов биоконтроля при бактеризации культур. Анализ численности фосфатмобилизующих бактерий свидетельствовал о высокой конкурентоспособности и успешной колонизации используемой бактериальной культуры Pseudomonas sp. PhS1 в корневой системе растений. Так, численность этой микробной группы в ризосфере пшеницы в опытных вариантах была в среднем в 5,5-7,2 раза выше, чем в контроле, а в ризосфере ячменя - в 2,1-3,2 раза.

3. Численность микроорганизмов (млн КОЕ/г а.с.в. почвы) в ризосфере мягкой пшеницы (Triticum aestivum L.) сорта Иргина и ячменя (Hordeum vulgare L.) сорта Ача при инокуляции семян бактериями, изолированными из копролитов дождевых червей $(M \pm \sigma$, п. Лучаново, Томская обл., 2015 год)

\begin{tabular}{|c|c|c|c|c|}
\hline \multirow{2}{*}{ Вариант } & \multirow{2}{*}{$\begin{array}{l}\text { Общая } \\
\text { численность }\end{array}$} & \multirow{2}{*}{\begin{tabular}{|} 
Фосфатмобили- \\
зующие бактерии
\end{tabular}} & \multicolumn{2}{|c|}{ Низшие грибы } \\
\hline & & & общая численность & Trichoderma \\
\hline \multicolumn{5}{|c|}{ Пше н ица } \\
\hline Контроль & $102,0 \pm 26,5$ & $2,1 \pm 0,2$ & $0,71 \pm 0,01$ & $0,01 \pm 0,002$ \\
\hline Pseudomonas sp. PhS1 & $121,0 \pm 38,4$ & $15,1 \pm 1,6^{*}$ & $0,24 \pm 0,03^{*}$ & $0,01 \pm 0,005$ \\
\hline Pseudomonas sp. (PhS1 + GS4) & $174,0 \pm 20,7^{*}$ & $11,6 \pm 2,9^{*}$ & $0,75 \pm 0,02$ & $0,05 \pm 0,008^{*}$ \\
\hline \multicolumn{5}{|c|}{ Я ч м е н ь } \\
\hline Контроль & $60,0 \pm 2,1$ & $5,0 \pm 0,2$ & $1,42 \pm 0,27$ & 0 \\
\hline Pseudomonas sp. PhS1 & $59,0 \pm 1,9$ & $10,7 \pm 0,9^{*}$ & $0,58 \pm 0,01^{*}$ & $0,07 \pm 0,007^{*}$ \\
\hline Pseudomonas sp. (PhS1 + GS4) & $94,0 \pm 1,5^{*}$ & $16,0 \pm 1,5^{*}$ & $0,67 \pm 0,07^{*}$ & $0,05 \pm 0,002 *$ \\
\hline * Различия с контролем стати & СКИ ЗН & $\mathrm{p}<0,05$. & & \\
\hline
\end{tabular}

Анализ данных литературы (12), а также результаты фитосанитарного обследования посевов зерновых культур, ежегодно проводимого ФГБУ Россельхозцентр в Томской области, свидетельствуют о том, что наиболее вредоносными заболеваниями зерновых культур в регионе остаются гельминтоспориозная и фузариозная корневая гниль, вызываемая Bipolaris sorokiniana (Sacc.) Shoemaker и Fusarium oxysporum Schleht (22, 24, 25). Наибольший вред заболевание причиняет твердой пшенице, ячменю, мягкой яровой пшенице и озимой ржи. Недобор урожая зерна пшеницы из-за болезней может достигать 19-20 \% и более, урожая ячменя - 25$30 \%$ и более $(22,24,25)$.

В 2013 году наблюдалось некоторое различие в эффективности вариантов бактеризации для пшеницы и ячменя (табл. 4). Так, для пшеницы наилучшие результаты были отмечены в вариантах с применением смеси 
бактериальных культур, где в фазу колошения-начала цветения наблюдались статистически значимые $(\mathrm{p}<0,05)$ снижения развития корневых гнилей на $34 \%$. Для ячменя наибольшее снижение пораженности растений корневыми гнилями в вегетационном эксперименте отмечали при бактеризации монокультурой бактерий Pseudomonas sp. GS4: на 32-41 и 39-44 \% соответственно в фазах кущения и цветения.

4. Основные показатели развития корневых гнилей на пшенице (Triticum aestivum L.) сорта Иргина и ячмене (Hordeum vulgare L.) сорта Ача при инокуляции семян бактериями, изолированными из копролитов дождевых червей ( $M \pm \sigma$, п. Лучаново, Томская обл.)

\begin{tabular}{|c|c|c|c|c|c|}
\hline \multirow[b]{2}{*}{ Культура } & \multirow[b]{2}{*}{ Вариант } & \multicolumn{2}{|c|}{ Кущение } & \multicolumn{2}{|c|}{ Начало цветения } \\
\hline & & $\begin{array}{l}\text { распростра- } \\
\text { ненность, \% }\end{array}$ & $\begin{array}{l}\text { индекс раз- } \\
\text { вития, \% }\end{array}$ & $\begin{array}{l}\text { распростра- } \\
\text { ненность, \% }\end{array}$ & $\begin{array}{l}\text { индекс раз- } \\
\text { вития, \% }\end{array}$ \\
\hline \multirow{4}{*}{ Пшеница } & & 2013 год & & & \\
\hline & Контроль & $49,2 \pm 3,9$ & $17,0 \pm 2,3$ & $51,7 \pm 3,6$ & $19,9 \pm 3,8$ \\
\hline & Pseudomonas sp. GS4 & $56,4 \pm 2,7$ & $16,4 \pm 1,0$ & $44,4 \pm 2,6^{*}$ & $18,6 \pm 3,5$ \\
\hline & Pseudomonas sp. (PhS1 + GS4) & $56,7 \pm 5,1$ & $18,0 \pm 1,2$ & $36,7 \pm 5,7^{*}$ & $13,2 \pm 2,6^{*}$ \\
\hline \multirow[t]{3}{*}{ Ячмень } & Контроль & $82,7 \pm 2,4$ & $39,5 \pm 2,6$ & $44,4 \pm 2,9$ & $14,7 \pm 2,6$ \\
\hline & Pseudomonas sp. GS4 & $53,3 \pm 7,6^{*}$ & $23,2 \pm 2,8^{*}$ & $24,4 \pm 8,1 *$ & $8,3 \pm 2,5^{*}$ \\
\hline & Pseudomonas sp. $(\mathrm{PhS} 1+\mathrm{GS} 4)$ & $\begin{array}{l}70,7 \pm 3,7^{*} \\
2014 \text { год }\end{array}$ & $27,3 \pm 3,6^{*}$ & $41,0 \pm 7,8$ & $13,3 \pm 2,5$ \\
\hline \multirow[t]{3}{*}{ Пшеница } & Контроль & $66,3 \pm 14,2$ & $26,7 \pm 4,8$ & $60,6 \pm 8,9$ & $20,4 \pm 3,7$ \\
\hline & Pseudomonas $\mathrm{sp} . \mathrm{PhS1}$ & $74,4 \pm 6,4$ & $27,3 \pm 3,6$ & $52,2 \pm 12,6$ & $17,2 \pm 8,5$ \\
\hline & Pseudomonas sp. $(\mathrm{PhS} 1+\mathrm{GS} 4)$ & $72,5 \pm 12,3$ & $25,9 \pm 3,3$ & $54,4 \pm 10,2$ & $20,8 \pm 7,4$ \\
\hline \multirow[t]{3}{*}{ Ячмень } & Контроль & $84,0 \pm 6,7$ & $41,3 \pm 4,0$ & $86,7 \pm 12,9$ & $43,6 \pm 10,6$ \\
\hline & Pseudomonas sp. PhS1 & $84,0 \pm 6,7$ & $37,5 \pm 7,6$ & $73,3 \pm 10,1$ & $35,5 \pm 7,6$ \\
\hline & Pseudomonas sp. (PhS1 + GS4) & $\begin{array}{r}80,8 \pm 5,1 \\
2015 \text { год }\end{array}$ & $36,9 \pm 4,1$ & $71,1 \pm 12,6$ & $30,5 \pm 10,7$ \\
\hline \multirow[t]{3}{*}{ Пшеница } & Контроль & $55,6 \pm 17,8$ & $31,2 \pm 3,8$ & $61,1 \pm 17,5$ & $21,7 \pm 6,6$ \\
\hline & Pseudomonas sp. PhS1 & $55,6 \pm 17,8$ & $27,5 \pm 4,0$ & $50,0 \pm 17,9$ & $15,8 \pm 4,2$ \\
\hline & Pseudomonas sp. $(\mathrm{PhS} 1+\mathrm{GS} 4)$ & $50,0 \pm 17,9$ & $26,7 \pm 7,6$ & $26,6 \pm 15,8^{*}$ & $9,2 \pm 3,7 *$ \\
\hline \multirow[t]{3}{*}{ Ячмень } & Контроль & $55,6 \pm 17,8$ & $21,7 \pm 5,5$ & $66,7 \pm 16,9$ & $28,3 \pm 3,7$ \\
\hline & Pseudomonas sp. PhS1 & $57,8 \pm 17,7$ & $22,5 \pm 6,1$ & $46,7 \pm 17,8$ & $14,2 \pm 5,0^{*}$ \\
\hline & Pseudomonas sp. $(\mathrm{PhS} 1+\mathrm{GS} 4)$ & $51,7 \pm 17,9$ & $22,5 \pm 7,8$ & $57,8 \pm 17,7$ & $20,8 \pm 3,8^{*}$ \\
\hline
\end{tabular}

Показатели развития корневых гнилей в вегетационном сезоне 2014 года были значительно выше, чем в 2013 году (см. табл. 4). Увеличение распространенности и развития корневых гнилей было связано с неблагоприятными для сельскохозяйственных культур условиями - холодной погодой с частыми осадками. Кроме того, для эффективной корневой колонизации растений инокулированными бактериями требуется температура не ниже $12{ }^{\circ} \mathrm{C}$, а оптимальная находится в промежутке $14-16{ }^{\circ} \mathrm{C}$ (13). В мае отмечался дефицит тепла, а среднемесячная температура составила $8,1^{\circ} \mathrm{C}$ (ниже нормы на $2,5^{\circ} \mathrm{C}$ ), что, по всей видимости, не позволило бактериям успешно заселить ризосферу растений, конкурировать с ее естественными обитателями и наиболее полно проявить протекторные и стимулирующие свойства. В результате в вегетационный период 2014 года в полевом эксперименте мы не выявили статистически значимого подавления корневых гнилей зерновых культур под влиянием бактериальной инокуляции. На протяжении всего сезона наблюдали лишь тенденцию к снижению развития болезни на пшенице и ячмене, причем четкой зависимости от вида бактеризации или способа инокуляции бактерий не обнаружили. Благоприятные погодные условия 2015 года оказали положительное влияние на фитосанитарную обстановку: распространенность корневых гнилей снизилась как в контрольных, так и опытных вариантах по сравнению с таковой в вегетационные периоды 2013 и 2014 годов. Значимое $(\mathrm{p}<0,05)$ снижение индекса развития корневых гнилей отмечали на пшенице и ячмене в фазу начала цветения (соответственно на 55-59 и 2528 \%) в вариантах с бактеризацией смесью культур, а для ячменя - также 
при использовании монокультуры Pseudomonas sp. PhS1 (на 48-51 \%).

В целом результаты учета корневых гнилей, полученные в наших экспериментах, показали эффективность комплексной бактеризации и подтвердили перспективность разработки микробных препаратов, основанных на взаимодополняющих ассоциациях микробных культур, которые сочетают в себе разнообразные функции - от обеспечения растений доступными источниками питания до стимулирования роста и защиты от фитопатогенов $(18,19)$. Аналогичные данные были получены нами и в полевых экспериментах в 2011 году (26). Бактериальные изоляты способствовали уменьшению распространенности корневых гнилей на посевах мягкой пшеницы и ячменя на 18-63 \%. При этом бактеризация штаммом Pseudomonas sp. GS4 обеспечила сопоставимое с эффектом химического фунгицида Дивиденд Стар уменышение развития корневых гнилей на пшенице в фазы кущения и выметывания колоса, а также на ячмене в фазу кущения. Бактеризация Pseudomonas sp. GS4 способствовала увеличению урожайности пшеницы и ячменя на 19,6 \%, повышению содержание белка и клейковины в зерне на 0,9-1,3 \% по сравнению с показателями при обработке химическим фунгицидом Дивиденд Стар.

Таким образом, выделенные из копролитов дождевых червей бактериальные штаммы рода Pseudomonas снижают общую зараженность семян пшеницы возбудителями семенных инфекций в лабораторных экспериментах. Наименьшая зараженность отмечается при бактеризации штаммом Pseudomonas sp. PhS1 (в 4 раза ниже контрольных показателей). Антифунгальная активность бактерий, обнаруженная в лабораторных опытах, коррелирует с их способностью подавлять развитие грибов - возбудителей корневых гнилей в условиях агроценоза. На протяжении трех вегетационных периодов инокуляция семян пшеницы и ячменя экспериментальными штаммами способствовала снижению индекса развития корневых гнилей, однако наблюдаемые колебания эффективности (5-58 \% в зависимости от культуры бактерий и погодных условий) требуют продолжения исследований для повышения стабильности бактериальных препаратов и оптимизации условий их применения.

\section{ЛИТЕРАТУРА}

1. Compant S., Duffy B., Nowak J, Clement C., Barka E.A. Use of plant growth-promoting bacteria for biocontrol of plant diseases: principles, mechanisms of action, and future prospects. Applied and Environmental Microbiology, 2005, 71(9): 4951-495 (doi:10.1128/AEM.71.9.49514959.2005).

2. Raupach G.S, Kloepper J.W. Mixtures of plant growth-promoting rhizobacteria enhance biological control of multiple cucumber pathogens. Phytopathology, 1998, 88(11): 1158-1164 (doi: 10.1094/PHYTO.1998.88.11.1158).

3. Johnson K.B. Pathogen refuge: a key to understanding biological control. Annu. Rev. Phytopathol., 2010, 48: 141-60 (doi: 10.1146/annurev.phyto.112408.132643).

4. Максимов И.В., Абизгильдина Р.Р., Пусенкова Л.И. Стимулирующие рост растений микроорганизмы как альтернатива химическим средствам защиты от патогенов (обзор). Прикладная биохимия и микробиология, 2011, 47(4): 373-385.

5. Gupta G., Parihar S.S., Ahirwar N.K., Snehi S.K., Singh V. Plant growth promoting rhizobacteria (PGPR): current and future prospects for development of sustainable agriculture. Journal of Microbial \& Biochemical Technology, 2015, 7: 096-102 (doi: 10.4172/1948-5948.1000188).

6. Berg G., Fritze A., Roskot N., Smalla K. Evaluation of potential biocontrol rhizobacteria from different host plants of Verticillium dahlia Kleb. J. Appl. Microbiol., 2001, 91: 963-971 (doi: 10.1046/j.1365-2672.2001.01462.x).

7. Georgakopoulos D.G., Fiddaman P., Leifert C., Malathrakis N.E. Biological control of cucumber and sugar beet damping-off caused by Pythium ultimum with bacterial and fungal antagonists. J. Appl. Microbiol., 2002, 92: 1078-1086 (doi: 10.1046/j.1365-2672.2002.01658.x).

8. Smyth E.M., McCarthy J., Nevin R., Khan M.R., Dow J.M., O'Gara F., Doohan F.M. In 
vitro analyses are not reliable predictors of the plant growth promotion capability of bacteria; a Pseudomonas fluorescens strain that promotes the growth and yield of wheat. J. Appl. Microbiol., 2011, 111(3): 683-692 (doi: 10.1111/j.1365-2672.2011.05079.x).

9. Акимова Е.Е., Блинова П.А., Минаева О.М., Терещенко Н.Н., Кравец А.В. Оценка активности бактериальных штаммов в модельных экспериментах. Мат. Межд. науч.-практ. конф. «Защита растений в современных технологиях возделывания сельскохозяйственных культур». Краснообск, 2013: 11-14.

10. Minaeva O.M., Akimova E.E. Effectiveness of applying bacteria Pseudomonas sp., strain B6798, for anti-phytopathogenic protection of crops in Western Siberia. Вестник Томского государственного университета. Биология, 2013, 3(23): 19-37.

11. Захаренко В.А. Биопестициды и средства защиты растений с небиоцидной активностью в интегрированном управлении фитосанитарным состоянием зерновых агроэкосистем. Агрохимия, 2015, 6: 64-76.

12. Кожемяков А.П., Белоброва С.Н., Орлова А.Г. Создание и анализ базы данных по эффективности микробных биопрепаратов комплексного действия. Сельскохозяйственная биология, 2011, 3: 112-115.

13. Benizri E., Baudon E., Guckert A. Root colonization by inoculated plant growth-promoting rhizobacteria. Biocontrol. Sci. Techn., 2001, 11: 557-574 (doi: 10.1080/09583150120076120).

14. Lugtenberg B., Kamilova F. Plant-growth-promoting rhizobacteria. Annu. Rev. Microbiol., 2009, 63: 541-56 (doi: 10.1146/annurev.micro.62.081307.162918).

15. George E., Kumar S.N., Jacob J., Bommasani B., Lankalapalli R.S., Morang P., Kumar B.S. Characterization of the bioactive metabolites from a plant growth-promoting rhizobacteria and their exploitation as antimicrobial and plant growth-promoting agents. Appl. Biochem. Biotech., 2015, 176: 529-546 (doi: 10.1007/s12010-015-1593-3).

16. Lutz M.P., Wenger S., Maurhofer M., Défago G., Duffy B. Signaling between bacterial and fungal biocontrol agents in a strain mixture. FEMS Microbiol. Ecol., 2004, 48: 447-455 (doi: 10.1016/j.femsec.2004.03.002).

17. Zhou D.-M., Wang K.-P., Liu H.-X., Gu C., Guo J.-H. Field evaluation of different application methods of the mixture of Bacillus cereus strain AR156 and Bacillus subtilis strain SM21 on pepper growth and disease resistance. Biocontrol. Sci. Techn., 2014, 24(12): 1451-1468 (doi: 10.1080/09583157.2014.945899).

18. Schisler D.A., Slininger P.J., Bothast R.J. Effects of antagonist cell concentration and twostrain mixtures on biological control of Fusarium dry rot of potatoes. Phytopathology, 1997, 87: 177-183 (doi: 10.1094/PHYTO.1997.87.2.177).

19. Xu X.-M., Jeffries P., Pautasso M., Jeger M.J. Combined use of biocontrol agents to manage plant diseases in theory and practice. Phytopathology, 2011, 101(9): 1024-1031 (doi: 10.1094/PHYTO-0810-0216).

20. Минаева О.М., Акимова Е.Е., Евдокимов Е.В. Кинетические аспекты ингибирования роста фитопатогенных грибов ризосферными бактериями. Прикладная биохимия и микробиология, 2008, 44(5): 565-570.

21. Чулкина В.А., Коняева Н.М., Кузнецова Т.Т. Борьба с болезнями сельскохозяйственных культур в Сибири. М., 1987.

22. Доспехов Б.А. Методика полевого опыта (с основами статистической обработки результатов исследований). М., 1985.

23. Определитель бактерий Берджи. T. 1 /Под ред. Дж. Хоулта, Н. Крига, П. Снита, Дж. Стейли, С. Уилльямса. М., 1997.

24. Торопова Е.Ю., Воробьева И.Г., Чулкина В.А., Мармулева Е.Ю. О роли биологического разнообразия в фитосанитарной оптимизации агроландшафтов. Сельскохозяйственная биология, 2013, 3: 12-17 (doi: d10.15389/agrobiology.2013.3.12rus).

25. Горобей И.М., Ашмарина Л.Ф. Оптимизация фитосанитарного состояния посевов ярового ячменя в лесостепной зоне Западной Сибири. Главный зоотехник, 2010, 5: 31-35.

26. Терещенко Н.Н., Кравец А.В., Акимова Е.Е., Минаева О.М., Зотикова А.П. Эффективность применения микроорганизмов, изолированных из копролитов дождевых червей, для увеличения урожайности зерновых культур. Сибирский вестник сельскохозяйственной науки, 2013, 5: 10-17.

${ }^{1}$ Сибирский НИИ сельского хозяйства и торфа - филиал ФГБУН Сибирского федерального научного центра

Поступила в редакцию агробиотехнологий $Р A H$,

634050 Россия, г. Томск, а/я 1668, ул. Гагарина, 3,

e-mail: mom05@mail.ru (₫ corresponding author), akimovanell@mail.ru, ternat@mail.ru, zyubanovat.i@gmail.com, kravets@sibmail.com;

2ФГАОУ ВО Национальный исследовательский

Томский государственный университет,

634050 Россия, г. Томск, пр. Ленина, 36,

e-mail: mari-09-90@mail.ru 


\title{
PSEUDOMONADS ASSOCIATED WITH SOIL LUMBRICIDES AS PROMISING AGENTS IN ROOT ROT BIOCONTROL FOR SPRING GRAIN CROPS
}

\author{
O.M. Minaeva1, 2, E.E. Akimova1, 2, N.N. Tereshchenko1, 2, A.V. Kravets', \\ T.I. Zyubanoval, 2 , M.V. Apenysheva ${ }^{2}$
}

${ }^{1}$ Siberian Research Institute of Agriculture and Peat - Branch of the Siberian Federal Scientific Center of Agro-Bio Technologies RAS, 3, ul. Gagarina, 1668 PO box, Tomsk, 634050 Russia, e-mail mom05@mail.ru ( $₫$ corresponding author), akimovanell@mail.ru, ternat@mail.ru, zyubanovat.i@gmail.com, kravets@sibmail.com;

${ }^{2}$ National Research Tomsk State University, 36, pr. Lenina, Tomsk, 634050 Russia, e-mail mari-09-90@mail.ru ORCID:

Minaeva O.M. orcid.org/0000-0002-5925-6022

Tereshchenko N.N. orcid.org/0000-0002-3084-6926

Apenysheva M.B. orcid.org/0000-0001-7677-6217

The authors declare no conflict of interests

Received July 5, 2017

\begin{abstract}
Akimova E.E. orcid.org/0000-0002-3279-8200
Zyubanova T.I. orcid.org/0000-0002-9429-9706

Kravets A.V. orcid.org/0000-0003-3057-8623
\end{abstract}

doi: 10.15389/agrobiology.2019.1.91eng

Abstract

Currently, crop yields can be increased by high farming standards which include environmentally friendly use of chemical fertilizers and pesticides, as well as their replacement by bioformulations having similar activity. That is why both search for new promising species, strains and isolates of bacterial antagonists for their potential use as biocontrol agents, and study of antifungal activity mechanisms, particularly the relationship between the activity in model tests and in agrocenoses, are relevant. The aim of this study was to estimate bacterial isolates from redworm coprolites as potential bioactive agents to control phytopathogenic fungi causing root rot of crops. The experiments were conducted in 2013-2015. In the preliminary laboratory screening for fungistatic and growth-promoting activity we selected two strains, Pseudomonas sp. GS4 and Pseudomonas sp. PhS1, and assessed their ability to decrease the growth rate of fungal colonies in Petri dish test on nutrient agar medium and to reduce seed infestation of soft wheat (Triticum aestivum L., Irgin cultivar) in sterile paper roll test. Seeds soaked in distilled water served as control. As a standard, we used seed treatment with a chemical fungicide Dividend ${ }^{\circledR}$ Star («Syngenta AG», Switzerland) (30 g/l difenoconazole, $6.3 \mathrm{~g} / 1$ cyproconazole) at recommended rates. In field tests, we recorded root rots in soft wheat Irgin cultivar plants and in barley (Hordeum vulgare L.) Acha cultivar plants during tillering and beginning of blooming. The laboratory tests showed a statistically significant $(\mathrm{p}<0.05) 1.5-2.5$-fold decrease in the growth rate of phytopathogenic fungi Fusarium oxysporum, Bipolaris sorokiniana and Alternaria spp. as compared to control. In all experiments with bacterization, there was a 53-76\% decrease $(\mathrm{p}<0.05)$ in total seed infestation by pathogens as compared to non-bacterized plants. The effect of the bacteria in planta was assessed in small model systems. The obtained data show a statistically significant $(\mathrm{p}<0.05)$ reduction in the root rot disease incidence in bacterization with Pseudomonas sp. GS4 (by 33-37 \%) and Pseudomonas sp. PhS1 (by 57-60 \%). Root rot disease severity decreases 2.1-2.4-fold and 3.3-3.5-fold, respectively. In 2015, we revealed a tendency towards a 19-70\% increase in the total number of rhizosphere microorganisms at the beginning of plant blooming depending on the crop and type of bacterization. The number of phosphate-mobilizing bacteria in the rhizosphere under bacterization was, on average, 5.5-7.2-fold higher in wheat and 2.1-3.2-fold higher in barley than that without bacterization. Our results of root rot field study in the 2013-2015 showed the efficacy of both monocultures and complex bacterization which provided a decrease in wheat and barley root rot disease severity by $6.5-57.6 \%$ and 18.6-50.0 \%, respectively, depending on the bacterial culture and the weather conditions. The maximum biological efficacy of the isolates is noted at the beginning of blooming.

Keywords: biocontrol, rhizobacteria, Pseudomonas, Eisenia fetida, antifungal activity, phytopathogen, Bipolaris, Alternaria.

\section{Научные собрания \\ SMi's 8th ANNUAL PHARMACEUTICAL MICROBIOLOGY UK}

(January 21-22, 2019, London, United Kingdom

Subdisciplines: microbiology, medicine, chemical engineering, biomedical engineering, life science, process engineering, toxicology, biotechnology, general \& internal medicine, medical computation \& informatics, pharmacy \& pharmacology, health science, knowledge transfer, medical ethics / bioethics, medical technology, systems engineering

Information: http://www.globaleventslist.elsevier.com/events/2016/02/parallel-trade/ 